\title{
Physical and chemical features of sapropelic mud of some freshwater lakes in the Elizovo district of the Kamchatka (Russia)
}

\author{
Rafael' $V$. Zharkov*1 \\ Dmitry N. Kozlov ${ }^{1}$ \\ Berta I. Chelnokova ${ }^{2}$
}

\author{
${ }^{1}$ Institute of Marine Geology and Geophysics, FEB RAS, \\ Yuzhno-Sakhalinsk, Russia \\ ${ }^{2}$ Institute of Medical Climatology and Rehabilitation Treatment, \\ Vladivostok, Russia
}

*E-mail:rafael_zharkov@mail.ru

\section{Abstract Peферат PDF RuS}

Firstly, the data on the physical and chemical properties of sapropel mud and morphology of the bottom of several freshwater lakes of the central part of Elizovo district of the Kamchatka have been represented. The Ovalnoe and Sinichkino lakes (district of Petropavlovsk-Kamchatsky sity), the Lesnoe lake (district of Paratunka village) and unnamed lake $2.5 \mathrm{~km}$ south of Malki village were explored in 2016. The aim of the research was to study the features of the physical and chemical properties of sapropels and to assess the prospects for balneotherapeutic and cosmetological use. The sapropel mud of the unnamed lake in the Malki village area was the most promising among the lakes surveyed. Physical indices of this dirt comply with the basic standards for therapeutic sapropel mud: humidity 71.28-95.27 \%, volume weight $1.13-1.14 \mathrm{~g} / \mathrm{cm}^{3}$, shear resistance value is $1128-1619$ dine $/ \mathrm{cm}^{2}$, heat capacity $0.95-0.98 \mathrm{cal} / \mathrm{g} \cdot \mathrm{deg}$, tackiness at $25^{\circ} \mathrm{C}$ is 2556-3714 dine $/ \mathrm{cm}^{2}$. The composition of mud solution is characterized as sulphate-hydrogen carbonate magnesium-sodium calcium. A content of biologically active elements is low (I $-0.05 \mathrm{mg} / \mathrm{dm}^{3} ; \mathrm{Br}-0.085 \mathrm{mg} / \mathrm{dm}^{3} ; \mathrm{B}<0.05 \mathrm{mg} / \mathrm{dm}^{3} ; \mathrm{H}_{2} \mathrm{SiO}_{3}-40.6 \mathrm{mg} / \mathrm{dm}^{3}$ ). By the sum of mineral substances $\left(\mathrm{M}-0.059 \mathrm{~g} / \mathrm{dm}^{3}\right)$ the mud solution refers to fresh, the $\mathrm{pH}$ of the mud is $5.2-$ 7.2, Eh reaches $-100 \mathrm{mV}$. Natural mud of the nameless lake located in the area of Malki village refers to therapeutic freshwater sulfide sapropel mud and can be used for balneological and cosmetic purposes with a wide range of indications. Additional experimental and clinical studies are necessary for the correct use of therapeutic dirt for therapeutic purposes.

\section{Keywords}

sapropel, lake morphology, geochemistry, balneology, Kamchatka

For citation: Zharkov R.V., Kozlov D.N., Chelnokova B.I. Physical and chemical features of sapropelic mud of some freshwater lakes in the Elizovo district of the Kamchatka (Russia). Geosystems of Transition Zones. 2019, vol. 3, no. 4, pp. 438-447. (In Russian) https://doi.org/10.30730/2541-8912.2019.3.4.438-447

Для цитирования: Жарков Р.В., Козлов Д.Н., Челнокова Б.И. Физические и химические особенности сапропелевых грязей некоторых пресноводных озер Елизовского района Камчатского края (Россия). Геосистемы переходных зон. 2019. Т. 3, № 4. С. 438-447. https://doi.org/10.30730/2541-8912.2019.3.4.438-447

\section{References}

1. Водяницкий Ю.Н. Концепция гибкого подхода к оценке ориентировочно допустимой концентрации тяжелых металлов и металлоидов в почве // Бюл. Почвенного института им. В.В. Докучаева. 2011. Вып. 67. С. 49-66.

2. Водяницкий Ю.Н. Нормативы содержания тяжелых металлов и металлоидов в почвах // Почвоведение. 2012. № 3. С. 368-375. 
3. Герасименко М.Ю., Астахов П.В., Бадалов Н.Г., Крикорова С.А., Персиянова-Дуброва А.Л., Львова Н.В., Барашков Г.Н., Уянаева А.И., Тупицина Ю.Ю., Мухина А.А., Истомина И.С., Поберская В.А., Кирьянова В.В. Пелоидотерапия в лечебно-реабилитационных и профилактических программах: клинические рекомендации // Физиотерапия, бальнеология и реабилитация. 2018. Т. 17, № 1. С. 4048.

4. Глотов В.Е., Глотова Л.П. Особенности распространения бальнеологических ресурсов СевероВостока России // Вестник ДВО РАН. 2007. № 6. С. 79-94.

5. Гринь Г.А., Мурзинцев П.П. О применении современных технических средств для высокоточной съемки рельефа дна и подводных объектов // Интерэкспо Гео-Сибирь. 2011. № 1. С. 102-107.

6. Жарков Р.В. Физико-химические свойства и перспективы использования сапропелевых грязей озера Большое Чибисанское (остров Сахалин) $=$ [Zharkov R.V. Physical and chemical properties and prospects of use of sapropelic mud of the Bolshoe Chibisanskoe Lake (Sakhalin Island)] // Геосистемы переходных зон $=$ Geosystems of Transition Zones. 2019. T. 3, № 3. C. 318-324. doi.org/10.30730/25418912.2019.3.3.318-324

7. Иванов Г.Н. Применение методов локации для изучения и разведки торфяных и сапропелевых отложений // Труды Инсторфа. 2011. Т. 56. № 3 . С. 39-52.

8. Карагулов Х.Г., Евсеева С.Б. Косметические средства на основе лечебных грязей: состав и технологические особенности // Современные проблемы науки и образования. 2015. № 1 (ч. 1). URL: www.science-education.ru/121-17850

9. Классификаџия минеральных вод и лечебных грязей для целей их сертификаиии: Методические указания № 2000/34 / А.Н. Разумов, В.Б. Адилов, О.Б. Давыдова и др. М.: РНЦ ВМиК, 2000. 150 с.

10. Козлов Д.Н. Кратерные озера Курильских островов. Южно-Сахалинск: Сахалин. обл. краеведч. музей, ИМГиГ ДВО РАН, 2015. 112 с.

11. Козлов Д.Н., Дегтерев А.В., Зарочинцев В.С. Кальдерное озеро Кольцевое: современное состояние и строение котловины (о. Онекотан, Курильские острова) $=$ [Kozlov D.N., Degterev A.V., Zarochintsev V.S. Koltsevoe caldera lake: current state and structure of the basin (Onekotan Island, Kuril Islands)] // Геосистемы переходных зон = Geosystems of Transition Zones. 2018. Т. 2, № 4. С. 359-364. doi: 10.30730/2541-8912.2018.2.4.359-364.

12. Козлов Д.Н., Жарков Р.В. Морфология и генезис озер кальдерных комплексов Головнина и Заварицкого (Курильские острова) // Вестник ДВО РАН. 2010. № 3. С 103-106.

13. Лопаткин Д.А., Шерстянкин П.П. Геоинформационное картографирование рельефа дна озера Байкал // Геодезия и картография. 2015. № 3. C. 22-28. DOI: 10.22389/0016-7126-2015-897-3-22-28

14. Мурадов С.В. Влияние минеральных вод Паратунского гидротермального месторождения на численность и геохимическую активность микроорганизмов илового сульфидного пелоида // Усnехи современного естествознания. 2018. № 5. С. 120-125.

15. Мурадов С.В. Мониторинг санитарно-микробиологического состояния лечебной грязи озера Утиного (Камчатский край) за 50 лет эксплуатации месторождения // Фундаментальные исследования. Биологические науки. 2013. № 6. С. 913-917.

16. Мурадов С.В. Формирование и биологическая активность грязе-иловых отложений. Владивосток: Дальнаука, 2000. 93 с.

17. Мурадов С.В., Рогатых С.В. Физико-химические свойства растворов лечебной грязи и основы технологии получения пелоидных препаратов // Научно-технический вестник Поволжья. Технические науки. 2013. № 3. С. 214-217.

18. Оказание услуг по созданию кадастра рекреационных ресурсов, проведение комплексного исследования и производства работ в области разведки и использования имеющихся природных ресурсов Сахалинской области: отчет о науч.-исслед. работе / исполн. Р.В. Жарков. Южно-Сахалинск: ИМГиГ ДВО РАН, 2014. 268 с. Инв. № 3664 (фонды ИМГиГ ДВО РАН).

19. Ориентировочно-допустимые конщентрации (ОДК) химических веществ в почве; Гигиенические нормативы. М.: Федеральный центр гигиены и эпидемиологии Роспотребнадзора, 2006. 11 с.

20. Предельно допустимые конщентрации (ПДК) химических веществ в почве: Гигиенические нормативы. М.: Федеральный центр гигиены и эпидемиологии Роспотребнадзора, 2006. 15 с.

21. Рянжин С.В., Субетто Д.А., Кочков Н.В., Ахметова Н.С., Вейнмейстер Н.А. Полярные озера мира: современные данные и состояние исследований // Водные ресурсы. 2010. Т. 37, № 4. С. 387-397.

22. СанПиН 42-128-4433-87. Санитарные нормы допустимых концентраций (ПДК) химических веществ в почве. М., 1988. 55 с.

23. Ступникова Н.А., Мурадов С.В. Физико-химические и микробиологические исследования лечебной грязи месторождения Озеро Утиное Камчатской области // Вестник ДВО РАН. 2005. № 3. С. 76-82.

24. Ступникова Н.А., Христофорова Н.К., Мурадов С.В. Месторождение лечебной грязи «Озеро Утиное»: условия формирования и оценка состояния при антропогенном воздействии // География $u$ природные ресурсы. 2003. № 4. С. 39-43.

25. Челнокова Б.И., Гвозденко Т.А. Минеральные воды и лечебные грязи Дальнего Востока: справочник. Владивосток: Изд-во ДВФУ, 2017. 220 с. 
26. Челнокова Б.И., Иванов Е.М., Гвозденко Т.А. Минеральные воды и лечебные грязи Дальнего Востока: справочник. Владивосток: Изд-во ДВФУ, 2010. 128 с.

27. Bouvet de Maisonneuve C., Eisele S., Forni F., Hamdi, Park E., Phua M., Putra R. Bathymetric survey of lakes Maninjau and Diatas (West Sumatra), and lake Kerinci (Jambi) // IOP Conf. Series: Journal of Physics: Conf. Series. 2019. Vol. 1185, № 012001. https://doi.org/10.1088/1742-6596/1185/1/012001

28. Florinsky I.V. Digital Terrain Analysis in Soil Science and Geology. 2nd ed. Amsterdam: Elsevier Acad. Press, 2016. 486 p.

29. Tibor G., Sade R., Hall J.K., Ben-Avraham Z., Nishri A. Lake bathymetry and bottom morphology // Lake Kinneret. Springer: Dordrecht, Netherlands, 2014. P. 59-68. https://doi.org/10.1007/978-94-017-8944-8_4 